\title{
Correction to: Genome analysis of Salmonella enterica subsp. diarizonae isolates from invasive human infections reveals enrichment of virulence-related functions in lineage ST1256
}

\author{
Joaquín Giner-Lamia ${ }^{1,2^{*}}$, Pablo Vinuesa ${ }^{3}$, Laura Betancor ${ }^{4}$, Claudia Silva $^{5}$, Julieta Bisio ${ }^{5}$, Lorena Soleto ${ }^{6,7}$, \\ José A. Chabalgoity ${ }^{4}$, José Luis Puente ${ }^{5}$, The Salmonella CYTED Network and Francisco García-del Portillo ${ }^{1 *}$
}

\section{Correction to: BMC Genomics (2019) 20:99 https://doi.org/10.1186/s12864-018-5352-z}

Following publication of the original article [1], the authors identified an error in the processing of the name of one of the members of The Salmonella CYTED Network.

M. Graciela Pucciarelli's middle name, Graciela, was erroneously processed as part of her Family name.

\section{Acknowledgments}

We are grateful to the members of the Salmoiber CYTED Network "Control de la salmonelosis en Iberoamérica" (215RT-0493): Fernando C. Soncini, Eleonora García-Vescovi (Universidad de Rosario-CONICET, Argentina); Griselda Flores, José Pedraza (Universidad Autónoma Gabriel René Moreno, Santa Cruz, Bolivia); Lucia Yim (Universidad de la República, Montevideo, Uruguay); Coralith García, Lizeth Astocondor, Theresa Ochoa, Noemí Hinostroza (Instituto de Medicina Tropical Alexander von Humboldt-Universidad Peruana Cayetano Heredia, Lima, Perú); and, M. Graciela Pucciarelli (Universidad Autónoma de Madrid, Centro de Biología Molecular Severo Ochoa CBMSO-, Madrid, Spain). Alfredo HernándezAlvarez and Victor del Moral from the Centro de Ciencias Genómicas, UNAM, are gratefully acknowledged for help with server system administration. We acknowledge support of the publication fee by the CSIC Open Access Publication Support Initiative through its Unit of Information Resources for Research (URICI).

\begin{abstract}
Author details
${ }^{1}$ Laboratorio de Patógenos Bacterianos Intracelulares, Centro Nacional de Biotecnología-Consejo Superior de Investigaciones Científicas (CNB-CSIC), Madrid, Spain. ${ }^{2}$ Centro de Biotecnología y Genómica de Plantas (CBGP), Universidad Politécnica de Madrid (UPM), Madrid, Spain. ${ }^{3}$ Centro de Ciencias Genómicas, Universidad Nacional Autónoma de México, Cuernavaca, Morelos, Mexico. ${ }^{4}$ Facultad de Medicina, Instituto de Higiene, Universidad de la República, Montevideo, Uruguay. ${ }^{5}$ Departamento de Microbiología Molecular, Instituto de Biotecnología, Universidad Nacional Autónoma de México, Cuernavaca, Morelos, Mexico. ${ }^{6}$ Ministerio de Salud de Bolivia, Centro Nacional de Enfermedades Tropicales (CENETROP), Santa Cruz, Bolivia.

${ }^{7}$ Universidad Autónoma Gabriel René Moreno, Santa Cruz, Bolivia.
\end{abstract}

Published online: 26 May 2020

Reference

1. Giner-Lamia J, Vinuesa P, Betancor L, et al. Genome analysis of Salmonella enterica subsp. diarizonae isolates from invasive human infections reveals enrichment of virulence-related functions in lineage ST1256. BMC Genomics. 2019;20:99 https://doi.org/10.1186/s12864-018-5352-z.
The original article can be found online at https://doi.org/10.1186/s12864018-5352-z.

* Correspondence: joaquin.giner@upm.es; fgportillo@cnb.csic.es

'Laboratorio de Patógenos Bacterianos Intracelulares, Centro Nacional de Biotecnología-Consejo Superior de Investigaciones Científicas (CNB-CSIC), Madrid, Spain

Full list of author information is available at the end of the article

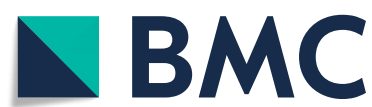

(0 The Author(s). 2020 Open Access This article is licensed under a Creative Commons Attribution 4.0 International License, which permits use, sharing, adaptation, distribution and reproduction in any medium or format, as long as you give appropriate credit to the original author(s) and the source, provide a link to the Creative Commons licence, and indicate if changes were made. The images or other third party material in this article are included in the article's Creative Commons licence, unless indicated otherwise in a credit line to the material. If material is not included in the article's Creative Commons licence and your intended use is not permitted by statutory regulation or exceeds the permitted use, you will need to obtain permission directly from the copyright holder. To view a copy of this licence, visit http://creativecommons.org/licenses/by/ $4.0 /$ The Creative Commons Public Domain Dedication waiver (http://creativecommons.org/publicdomain/zero/1.0/) applies to the data made available in this article, unless otherwise stated in a credit line to the data. 